\title{
Penerapan Aplikasi I00I Majas guna mempermudah pemahaman majas siswa SMA di Kota Malang
}

\section{Dini Anggita Sumantri ${ }^{*}$, Wulan Ria Anggraini ${ }^{2}$, Purwati Anggraini ${ }^{3}$}

Program Studi Pendidikan Bahasa Indonesia, Fakultas Keguruan dan Ilmu Pendidikan, Universitas Muhammadiyah Malang dinianggita26@gmail.com,wulanria82@gmail.com,poer1979ang@gmail.com

*Corresponding author: dinianggita26@gmail.com

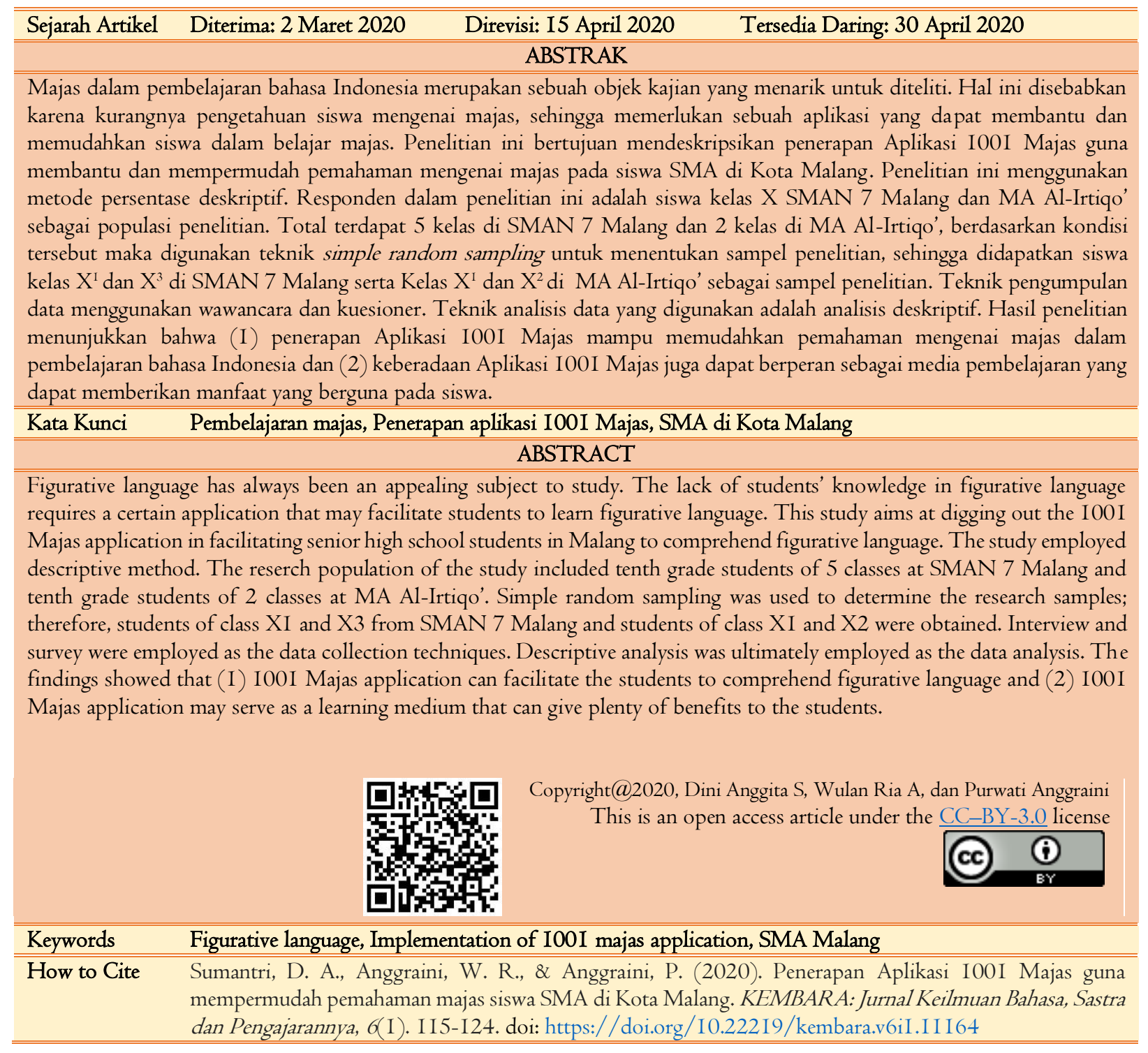

\section{PENDAHULUAN}

Bahasa sering dipahami sebagai alat untuk berkomunikasi antara manusia dengan manusia lain yang menggunakan sistem, tanda, atau petunjuk, misalnya gerakan atau kata (Dhieni \& Fridani, 2007). Bahasa Indonesia digunakan sebagai alat untuk berkomunikasi oleh penduduk Indonesia. Dalam komunikasi terdapat komunikator yang memulai komunikasi. Lalu, mengolah gagasan atau hal yang disampaikan oleh komunikator agar mampu diterima oleh lawan komunikasi dengan tepat. Dengan demikian, bahasa Indonesia harus dapat menyampaikan tujuan/maksud komunikator dengan jelas dan tepat. Mantan Menteri Pendidikan dan Kebudayaan Republik Indonesia Prof. Dr. Muhadjir Effendy, M.AP, menegaskan bahwa selain sebagai alat komunikasi, bahasa Indonesia juga merupakan identitas 
bangsa yang penggunanya mencapai 360 juta orang (JPNN, 2016). Banyaknya penggunaan bahasa Indonesia telah terimplementasikan dalam aneka ragam kehidupan, salah satunya adalah sastra. Pada ragam sastra tersebut, penggunaan bahasa dapat terwujud dalam bentuk gaya bahasa atau majas.

Majas juga sering diartikan bahasa yang indah dan digunakan untuk membandingkan suatu benda dengan benda lain (Wahyuni, Semi, \& Hamidin, 2012). Majas digunakan dalam sebuah karya sastra untuk menciptakan efek yang lebih kaya, lebih efektif, dan lebih sugestif dalam karya sastra (Permana, 20I7). Menurut Pradopo (2017), majas menyebabkan karya sastra menjadi menarik perhatian, menimbulkan kesegaran, lebih hidup, dan menimbulkan kejelasan gambaran angan. Secara umum fungsi dari majas yaitu menghasilkan kesenangan imajinatif, menghasilkan imaji tambahan, sehingga hal-hal abstrak menjadi konkret, menambah intensitas perasaan pengarang dalam menyampaikan makna dan sikapnya. Selain itu, majas juga berfungsi untuk mengonsentrasikan makna yang hendak disampaikan serta cara-cara menyampaikan sesuatu dengan bahasa yang singkat. Dalam buku Pedoman Umum Ejaan Bahasa Indonesia yang Disempurnakan (Tim Pengembangan Pedoman Bahasa Indonesia, 2016), terdapat 4 jenis kategori secara umum tentang majas di antaranya: (I) majas penegasan, (2) majas sindiran, (3) majas pertentangan, dan (4) majas perbandingan.

Menurut Munir (2013) majas dianggap sebagai penunjang gaya bahasa. Hal ini berarti, gaya bahasa lebih luas dibandingkan majas. Penggunaan majas yang tepat dapat menarik perhatian penerimanya, namun bila pemakaiannya tidak tepat, pemakaian majas dapat tidak maksimal, bahkan dapat merisaukan atau mengganggu pembaca. Pemakaian majas juga mampu membangkitkan suatu hal yang ingin dikemukakan dalam teks, karena majas mampu mengutarakan atau memperlihatkan ide maupun gagasan yang penuh arti melalui kalimat singkat (Anggraini, Sumantri, Purnomo, \& Anggraini, 2019). Majas diajarkan pada pembelajaran bahasa Indonesia di Sekolah Menengah Atas, khususnya pada kelas X semester 2. Terdapat beberapa Kompetensi Dasar (KD) yang ingin dicapai dalam pembelajaran bahasa Indonesia terkait dengan majas, yaitu (I) mampu menemukan majas dalam teks fiksi, (2) mampu menggunakan majas untuk menulis fiksi, dan (3) mengungkapkan jenis-jenis majas. Dengan demikian, apabila siswa mampu mencapai KD dalam pembelajaran majas tersebut, maka siswa lebih mudah mengapresiasi dan memproduksi karya sastra. Berdasarkan hasil observasi yang telah dilakukan, ditemukan bahwa siswa masih mengalami kesulitan dalam pembuatan karya sastra, salah satu penyebabnya adalah kurangnya pemahaman tentang majas. Hal ini ditandai dengan banyaknya siswa SMA yang belum memahami keberagaman majas, sehingga masih mengalami kesulitan untuk membuat karya sastra. Selain itu, sarana atau media di sekolah pun masih kurang mendukung untuk menyelenggarakan pembelajaran majas. Oleh karena itu, diperlukan kolaborasi dengan teknologi untuk menghasilkan media pembelajaran yang baik.

Hal ini tidak dapat dipisahkan dari perkembangan teknologi yang begitu pesat, kondisi tersebut perlu dimanfaatkan dengan baik, sehingga dapat mempermudah proses pembelajaran serta membuat proses pembelajaran menjadi efektif dan efisien (Wulandari, Suyanto, \& Fuad, 20I5). Media pembelajaran saat ini telah mengalami perubahan yang begitu signifikan, khususnya pada kemajuan teknologi sehingga lebih memudahkan guru dan siswa (Maharani, 2015). Selain itu, media pembelajaran telah dijadikan sebagai salah satu bagian penting dari upaya perubahan dalam proses kegiatan belajar mengajar (KBM) melalui interaksi antara teknologi dan komunikasi (Maharani, 20I5).

Pembelajaran pada abad 2I tidak dapat terlepas dari perkembangan teknologi yang begitu pesat dan masif (Oktaviani \& Marginingsih, 2018). Kondisi tersebut mengharuskan pendidikan terbuka terhadap masuknya teknologi dalam dunia pendidikan, salah satunya adalah kehadiran teknologi komunikasi dalam dunia pendidikan (Husain, 20I4). Kehadiran teknologi komunikasi dalam dunia pendidikan telah ditunjukkan dengan keberadaan telepon pintar atau gawai yang telah bertransformasi menjadi gudang informasi bagi guru dan juga siswa (Kartikasari, 2016). Keberadaan gawai menjadi sebuah gaya baru dalam proses pembelajaran dewasa ini, sehingga memudahkan siswa untuk mengakses materi atau informasi dengan cepat (Muhson, 2010). Selain itu, kehadiran perangkat lunak yang dapat diakses oleh gawai melalui platform android atau ios juga menjadi salah satu penunjang dalam pembelajaran. Kondisi tersebut mendorong peneliti untuk menciptakan perangkat lunak sebagai media pembelajaran 
dalam bentuk Aplikasi I00I Majas. Diharapkan melalui aplikasi ini proses pembelajaran majas tidak lagi menjadi satu hal sulit bagi siswa, sehingga Kompetensi Dasar (KD) yang ingin dicapai dalam pembelajaran bahasa Indonesia terkait dengan majas dapat tercapai.

Penelitian lain mengenai majas yang telah dilakukan, lebih banyak menyoroti majas yang terdapat dalam novel, kumpulan puisi, dan lirik lagu sebagai objek kajiannya. Seperti halnya penelitian yang dilakukan (Dermawan \& Santoso, 2017; Munir, 2013; Permana, 2017; Wahyuni et al., 2012; Wulandari et al., 2015; Yono \& Mulyani, 2017), kelima penelitian ini menekankan pada majas yang terdapat dalam novel, kumpulan puisi, dan lirik lagu. Penelitian lain yang dilakukan mengenai pengembangan media pembelajaran majas yang berbasis teknologi telah dilakukan oleh (Anggraini et al., 2019). Sejauh pemahaman peneliti, belum pernah ada penelitian sebelumnya yang membahas tentang penerapan Aplikasi I00I Majas guna mempermudah pemahaman siswa mengenai majas. Penelitian semacam ini dapat mengungkapkan berbagai informasi yang sangat berharga sebagai dasar untuk menyelenggarakan pembelajaran sastra yang berkaitan dengan majas. Berdasarkan uraian latar belakang yang telah dijelaskan, dapat dirumuskan permasalahan yang ada yaitu, kurangnya pemahaman majas pada siswa SMA di Kota Malang. Sejalan dengan itu, tujuan penelitian ini ialah mendeskripsikan penerapan Aplikasi I00I Majas guna membantu dan mempermudah pemahaman mengenai majas pada siswa SMA di Kota Malang.

\section{METODE}

Penelitian ini menggunakan metode persentase deskriptif, metode tersebut dipilih karena dapat membantu peneliti untuk menemukan dan menentukan data, serta menggambarkan hasil penelitian. Responden dalam penelitian ini adalah siswa kelas X SMAN 7 Malang dan MA Al-Irtiqo' sebagai populasi penelitian. Total terdapat 5 kelas di SMAN 7 Malang dan 2 kelas di MA Al-Irtiqo', berdasarkan kondisi tersebut maka digunakan simple random sampling yang digunakan untuk menentukan sampel penelitian, sehingga didapatkan siswa kelas $\mathrm{X}^{1}$ dan $\mathrm{X}^{3}$ di SMAN 7 Malang serta Kelas $\mathrm{X}^{1}$ dan $\mathrm{X}^{2}$ di MA Al-Irtiqo' sebagai sampel penelitian. Jumlah siswa di kelas $X^{1}$ di SMAN 7 sebanyak 30 siswa, jumlah siswa kelas $\mathrm{X}^{3}$ di SMAN 7 sebanyak 30 siswa, sedangkan jumlah siswa kelas $\mathrm{X}^{\mathrm{I}}$ di MA Al-Irtiqo' sebanyak 2I siswa, serta jumlah siswa kelas $X^{2}$ di MA Al-Irtiqo' sebanyak 19 orang. Terpilihnya dua kelas di SMAN 7 Malang dan MA Al-Irtiqo' dikarenakan materi mata pelajaran bahasa Indonesia yang membahas tentang majas. Penelitian dilakukan pada bulan Mei-Juni 2018 di SMAN 7 Malang dan MA Al-Irtiqo' Kota Malang.

Instrumen pengumpulan data dalam penelitian ini menggunakan wawancara dan kuesioner. Wawancara yang dilakukan pada beberapa siswa kelas X SMAN 7 Malang dan MA Al-Irtiqo' bersifat semiformal untuk memperoleh informasi tentang Aplikasi IO0I Majas. Kuesioner yang telah disiapkan terdiri dari 20 poin pertanyaan yang bersifat tertutup dan terbuka. Pertanyaan bersifat tertutup untuk menggali pemahaman majas siswa sebelum menggunakan Aplikasi IOOI Majas, sedangkan pertanyaan yang bersifat terbuka untuk menggali pemahaman majas siswa sesudah menggunakan Aplikasi IOOI Majas. Teknik analisis data yang digunakan dalam penelitian ini adalah deskriptif. Analisis deskriptif digunakan untuk memperoleh data tentang efektivitas penerapan Aplikasi IOOI Majas dalam pembelajaran majas di sekolah. Analisis data dilakukan dengan memilih, mengurutkan, mengelompokkan, data yang sudah ada, meringkasnya dan menyajikannya dalam bentuk naratif. Presentasi hasilnya analisis data kualitatif dibuat dalam bentuk deskripsi singkat, atau tabel yang disesuaikan dengan sifat data yang dianalisis.

\section{HASIL DAN PEMBAHASAN}

Berdasarkan kuesioner yang telah didistribusikan di kelas $\mathrm{X}^{1}$ dan $\mathrm{X}^{3}$ di SMAN 7 Malang, serta kelas $\mathrm{X}^{1}$ dan $\mathrm{X}^{2}$ di MA Al-Irtiqo' didapatkan sebanyak $\mathrm{I00}$ tanggapan dari empat kelas yang tersebut, jumlah tersebut sama dengan jumlah sampel yang telah ditentukan. Hasil penelitian menunjukkan bahwa penerapan Aplikasi IOOI Majas guna mempermudah pemahaman mengenai majas pada siswa SMA di 
Malang menunjukkan hasil yang sangat positif. Detail hasil penelitian dapat dilihat pada Tabel I berikut ini.

Tabel I. Kuesioner sebelum Aplikasi Diterapkan

\begin{tabular}{|c|c|c|c|c|c|c|c|c|}
\hline \multirow[b]{2}{*}{ No } & \multirow[b]{2}{*}{$\begin{array}{l}\text { Pemahaman umum } \\
\text { terhadap majas }\end{array}$} & \multicolumn{4}{|c|}{ Skala } & \multirow[b]{2}{*}{$\begin{array}{c}\text { Skala } \\
\text { Persentase } \\
\text { tertinggi }\end{array}$} & \multirow[b]{2}{*}{$\begin{array}{c}\text { Rata- } \\
\text { rata }\end{array}$} & \multirow[b]{2}{*}{ Kategori } \\
\hline & & $\begin{array}{l}\text { Sangat } \\
\text { Tidak } \\
\text { Setuju }\end{array}$ & $\begin{array}{l}\text { Tidak } \\
\text { Setuju }\end{array}$ & Setuju & $\begin{array}{l}\text { Sangat } \\
\text { Setuju }\end{array}$ & & & \\
\hline I & $\begin{array}{l}\text { Mempelajari majas di } \\
\text { sekolah pada mata } \\
\text { pelajaran bahasa } \\
\text { Indonesia }\end{array}$ & 3 & 3 & 38 & 56 & $56 \%$ & & $\begin{array}{l}\text { Sangat } \\
\text { Setuju }\end{array}$ \\
\hline 2 & $\begin{array}{l}\text { Terdapat } 4 \text { jenis majas } \\
\text { yaitu (I) majas } \\
\text { perbandingan, (2) } \\
\text { majas pertentangan, } \\
\text { (3) majas sindiran, dan } \\
\text { (4) majas penegasan. }\end{array}$ & 2 & 0 & 34 & 64 & $64 \%$ & & $\begin{array}{l}\text { Sangat } \\
\text { Setuju }\end{array}$ \\
\hline 3 & $\begin{array}{l}\text { Majas dapat } \\
\text { memperindah kata } \\
\text { dalam karya sastra } \\
\text { seperti puisi, novel, } \\
\text { dan cerpen }\end{array}$ & 2 & 3 & 20 & 75 & $75 \%$ & & $\begin{array}{l}\text { Sangat } \\
\text { Setuju }\end{array}$ \\
\hline 4 & $\begin{array}{l}\text { Majas dapat } \\
\text { membantu dalam } \\
\text { penulisan karya tulis } \\
\text { ilmiah }\end{array}$ & 5 & I5 & 33 & 47 & $47 \%$ & & $\begin{array}{l}\text { Sangat } \\
\text { Setuju }\end{array}$ \\
\hline 5 & $\begin{array}{l}\text { Mengusai materi } \\
\text { majas, terutama pada } \\
\text { macam-macam majas } \\
\text { dari } 4 \text { jenis besar. }\end{array}$ & 2 & 3 & 55 & 40 & $50 \%$ & $52,8 \%$ & Setuju \\
\hline 6 & $\begin{array}{l}\text { Buku dan internet } \\
\text { dapat mempermudah } \\
\text { dalam memahami } \\
\text { majas }\end{array}$ & 5 & I0 & 52 & 33 & $52 \%$ & & Setuju \\
\hline 7 & $\begin{array}{l}\text { Tidak pernah } \\
\text { menggunakan aplikasi } \\
\text { majas }\end{array}$ & 7 & 3 & 48 & 52 & $52 \%$ & & $\begin{array}{l}\text { Sangat } \\
\text { Setuju }\end{array}$ \\
\hline 8 & $\begin{array}{l}\text { Jika ada aplikasi majas } \\
\text { tidak perlu terhubung } \\
\text { jaringan internet ketika } \\
\text { menggunakannya }\end{array}$ & 8 & 12 & 37 & 43 & $43 \%$ & & $\begin{array}{l}\text { Sangat } \\
\text { Setuju }\end{array}$ \\
\hline 9 & $\begin{array}{l}\text { Tidak hanya jurusan } \\
\text { bahasa Indonesia saja } \\
\text { yang dapat manfaat } \\
\text { dari pembelajaran } \\
\text { majas }\end{array}$ & 8 & 22 & 33 & 37 & $37 \%$ & & $\begin{array}{l}\text { Sangat } \\
\text { Setuju }\end{array}$ \\
\hline I0 & $\begin{array}{l}\text { Pembelajaran majas } \\
\text { sangatlah penting } \\
\text { untuk pembuatan } \\
\text { karya sastra. }\end{array}$ & 3 & 7 & 38 & 52 & $52 \%$ & & $\begin{array}{l}\text { Sangat } \\
\text { Setuju }\end{array}$ \\
\hline
\end{tabular}

Berdasarkan data pada Tabel I, didapatkan infromasi awal mengenai pemahaman siswa kelas X di SMAN 7 Malang dan MA Al-Irtiqo'. Sebanyak 38 dan 56 siswa memberikan respon setuju dan sangat setuju terhadap pertanyaan mengenai majas dalam pembelajaran bahasa Indonesia. Hal ini menandakan bahwa majas memiliki peranan penting dalam mata pelajaran bahasa Indonesia yang terdapat kurikulum di tingkat SMP dan SMA (Anggraini et al., 2019). Selain itu, majas juga menjadi salah satu bagian dari bahasa Indonesia yang dapat membantu memperindah kata dalam karya sastra serta membantu dalam 
proses penulisan karya ilmiah (Dermawan \& Santoso, 2017; Ekoyanantiasih, 2015). Keberadaan majas dalam bahasa Indonesia telah dibuktikan dengan hasil kuesioner pada Tabel I sebanyak 64\% dan 75\% siswa sangat setuju bahwa majas adalah bagian dari bahasa Indonesia. Beberapa pertanyaan di bagian akhir menunjukkan bahwa pengetahuan majas siswa masih perlu ditingkatkan kembali yang terlihat pada poin 5 hingga IO. Selain itu, dengan adanya harapan siswa mengenai aplikasi yang mudah digunakan yang tidak terhubung dengan jaringan internet ketika menggunakannya (Kastolani, 2015; Munawar \& Sufa'atin, 2016) dan anggapan siswa bahwa penting pembelajaran majas dalam memproduksi karya sastra (Anggraini et al., 2019). Hal ini dibuktikan dengan jumlah respon sebanyak 48 dan 52 yang menyatakan setuju dan sangat setuju akan kehadiran sebuah aplikasi yang memudahkan pembelajaran majas, sehingga pembuatan dan penerapan Aplikasi IOOI Majas perlu dilakukan.

Berdasarkan hasil kuesioner yang tertera pada Tabel I, dibutuhkan sebuah aplikasi yang dapat memudahkan proses pembelajaran majas. Aplikasi yang telah dibuat bernama Aplikasi IOOI majas, diharapkan kehadiran aplikasi ini dapat menjadi penunjang pembelajaran bahasa Indonesia khususnya tentang majas. Hal ini dibuktikan dengan hasil kuesioner siswa kelas X pada Tabel 2 sebagaimana berikut ini. 
Tabel 2. Kuesioner sesudah Aplikasi Diterapkan

\begin{tabular}{|c|c|c|c|c|c|c|c|c|}
\hline \multirow[b]{2}{*}{ No } & \multirow[b]{2}{*}{$\begin{array}{l}\text { Pemahaman umum } \\
\text { terhadap majas }\end{array}$} & \multicolumn{4}{|c|}{ Skala } & \multirow[b]{2}{*}{$\begin{array}{c}\text { Skala } \\
\text { Persentase } \\
\text { tertinggi }\end{array}$} & \multirow[b]{2}{*}{$\begin{array}{c}\text { Rata- } \\
\text { rata }\end{array}$} & \multirow[b]{2}{*}{ Kategori } \\
\hline & & $\begin{array}{l}\text { Sangat } \\
\text { Tidak } \\
\text { Setuju } \\
\end{array}$ & $\begin{array}{l}\text { Tidak } \\
\text { Setuju }\end{array}$ & Setuju & $\begin{array}{l}\text { Sangat } \\
\text { Setuju }\end{array}$ & & & \\
\hline I & $\begin{array}{l}\text { Majas adalah gaya } \\
\text { bahasa. }\end{array}$ & 44 & 20 & 20 & 16 & $44 \%$ & & $\begin{array}{l}\text { Sangat } \\
\text { Tidak } \\
\text { Setuju }\end{array}$ \\
\hline 2 & $\begin{array}{l}\text { Majas sangat penting } \\
\text { bagi siswa terutama } \\
\text { dalam pelajaran bahasa } \\
\text { Indonesia. }\end{array}$ & 2 & 8 & 20 & 70 & $70 \%$ & & $\begin{array}{l}\text { Sangat } \\
\text { Setuju }\end{array}$ \\
\hline 3 & $\begin{array}{l}\text { Siswa hanya } \\
\text { mengetahui majas jenis } \\
\text { hiperbola. }\end{array}$ & 8 & 7 & 25 & 60 & $60 \%$ & & $\begin{array}{l}\text { Sangat } \\
\text { Setuju }\end{array}$ \\
\hline 4 & $\begin{array}{l}\text { Mengunduh Aplikasi } \\
\text { I00I Majas yang } \\
\text { terdapat di Google } \\
\text { Playstore. }\end{array}$ & 0 & 5 & I0 & 85 & $85 \%$ & & $\begin{array}{l}\text { Sangat } \\
\text { Setuju }\end{array}$ \\
\hline 5 & $\begin{array}{l}\text { Tampilan/desain dari } \\
\text { Aplikasi IOOI Majas } \\
\text { menarik. }\end{array}$ & 0 & 0 & I3 & 87 & $87 \%$ & & $\begin{array}{l}\text { Sangat } \\
\text { Setuju }\end{array}$ \\
\hline 6 & $\begin{array}{l}\text { Aplikasi IOOI Majas } \\
\text { memiliki konten yang } \\
\text { lengkap seperti materi, } \\
\text { komik, dan permainan } \\
\text { yang belum terdapat } \\
\text { pada aplikasi majas } \\
\text { lainnya. }\end{array}$ & 0 & I & I0 & 89 & $89 \%$ & & $\begin{array}{l}\text { Sangat } \\
\text { Setuju }\end{array}$ \\
\hline 7 & $\begin{array}{l}\text { Konten pada Aplikasi } \\
\text { IO0I Majas terdapat } \\
\text { permainan yang seru } \\
\text { yang berisi kalimat } \\
\text { bermajas, sehingga } \\
\text { dapat memperkaya } \\
\text { pemahaman majas } \\
\text { siswa. }\end{array}$ & 0 & 0 & II & 89 & $89 \%$ & $80,4 \%$ & $\begin{array}{l}\text { Sangat } \\
\text { Setuju }\end{array}$ \\
\hline 8 & $\begin{array}{l}\text { Materi pada Aplikasi } \\
\text { IO0I Majas } \\
\text { bermanfaat, karena } \\
\text { menampilkan definisi } \\
\text { majas beserta } \\
\text { contohnya yang dapat } \\
\text { menginspirasi untuk } \\
\text { membuat kalimat } \\
\text { majas lainnya dan } \\
\text { dalam pembuatan } \\
\text { karya sastra. }\end{array}$ & 0 & 0 & I0 & 90 & $90 \%$ & & $\begin{array}{l}\text { Sangat } \\
\text { Setuju }\end{array}$ \\
\hline 9 & $\begin{array}{l}\text { Aplikasi IOOI Majas } \\
\text { sangat bermanfaat } \\
\text { dalam pembelajaran. }\end{array}$ & 0 & 0 & 5 & 95 & $95 \%$ & & $\begin{array}{l}\text { Sangat } \\
\text { Setuju }\end{array}$ \\
\hline IO & $\begin{array}{l}\text { Adanya aplikasi IOOI } \\
\text { Majas dalam } \\
\text { pembelajaran sangat } \\
\text { membantu siswa } \\
\text { dalam memahami } \\
\text { majas. }\end{array}$ & 0 & 0 & 5 & 95 & $95 \%$ & & $\begin{array}{l}\text { Sangat } \\
\text { Setuju }\end{array}$ \\
\hline
\end{tabular}


Berdasarkan hasil kuesioner yang peroleh pada Tabel 2, dari responden siswa SMA di Kota Malang dapat merasakan manfaat setelah menggunakan Aplikasi IOOI Majas. Siswa merasakan lebih mudah untuk memahami pembelajaran utamanya saat mengerjakan tugas bahasa Indonesia yang berkaitan dengan materi majas. Hal ini menandakan bahwa keberadaan teknologi dalam pembelajaran sangat berpengaruh (Hakiky, 2020; Muhson, 2010) dalam menciptakan media pembelajaran yang menarik (Nurseto, 20II; Pujiastuti, Idrus, \& Emosda, 20I4; Sugiarti, 20I5) dalam proses pembelajaran. Awalnya siswa kurang memahami tentang majas, tetapi melalui Aplikasi IOOI Majas, siswa perlahan mulai dapat memahami dan lebih mengetahui majas beserta fungsinya (Susanti, Abdurahman, \& Ismail, 2013; Wahyuni et al., 2012; Yono \& Mulyani, 2017). Selain itu, sejumlah 95 siswa juga menyampaikan bahwa Aplikasi IOOI Majas dapat dipelajari dengan mudah serta kapan dan dimana saja.

Aplikasi IOOI Majas mampu mempermudah pembelajaran majas, hal ini dapat dilihat dari pengguna yang memberikan penilaian dan komentar yang positif berdasarkan konten, materi, komik, dan permainan. Hal ini terbukti dari kolom komentar di google playstore tentang Aplikasi IOOI Majas yang berjumlah I8 komentar. Berdasarkan penilaian dan komentar terhadap tampilan Aplikasi I00I Majas, menandakan bahwa aplikasi ini telah memenuhi syarat sebagai media pembelajaran yang dapat memberikan pengalaman yang bermakna pada siswa (Pujiastuti et al., 20I4). Selain itu, konten, materi, komik, dan permainan yang terdapat pada Aplikasi IOOI Majas juga dapat membantu untuk mengasah pemahaman jenis-jenis majas (Santoso, 2016; Yono \& Mulyani, 2017). Pada menu materi tersebut juga terdapat contoh yang dapat memperkuat pemahaman pengguna aplikasi. Konten yang paling banyak dinikmati oleh pengguna Aplikasi IOOI Majas yakni komik dan permainan. Hal ini dikarenakan konten komik dan permainan pada aplikasi sesuai dengan tingkat dan minat siswa yang masih berada di bangku SMA (Lubis \& Ikhsan, 2015; Yektyastuti \& Ikhsan, 20I6), sehingga menjadikan salah satu keunggulan dari Aplikasi IO0I Majas dibandingkan dengan aplikasi-aplikasi sebelumnya.

\section{Hasil Wawancara}

Setelah membagikan kuesioner, penelitian dilanjutkan menggunakan metode wawancara. Sampel wawancara dipilih menggunakan simple random sampling yang memilih 5 siswa dari setiap kelasnya. Wawancara terdiri dari lima pertanyaan terkait dengan penggunaan Aplikasi I00I Majas sebagai media pembelajaran. Berdasarkan hasil wawancara terhadap 20 siswa yang telah dipilih, dapat disimpulkan bahwa tanggapan mereka terhadap penerapan Aplikasi I00I Majas sangat memuaskan, menyenangkan atau positif. Siswa Kelas X SMAN 7 Malang menyatakan bahwa Aplikasi IO0I Majas memiliki tampilan yang bagus, materinya bermanfaat, dan permainan yang menarik. Selain itu, siswa kelas X MA Al-Irtiqo' Malang menyatakan bahwa aplikasi sangat menarik, mudah digunakan, bermanfaat, permainan yang seru, dan membantu dalam mencari majas ketika membuat puisi.

Hasil penelitian ini telah memberikan informasi bahwa siswa dapat mengetahui lebih dalam mengenai majas yang berhubungan dengan Kompetensi Dasar kelas X pada KD (3.I7) menganalisis unsur pembangun puisi dan $\mathrm{KD}$ (4.17) menulis puisi dengan memerhatikan unsur pembangunnya (tema, diksi, gaya bahasa, imaji, struktur perwajahan) (Indriyani, Sukirno, \& Bagiya, 20I4). Pada kelas XI terdapat pula KD (3.20) mengenai menganalisis pesan dari dua buku fiksi (novel dan buku kumpulan puisi yang dibaca dan KD (4.20) terkait menyusun ulasan terhadap pesan dari dua buku kumpulan puisi yang dikaitkan dengan situasi kekinian. Tidak hanya itu, untuk kelas XII terdapat KD (3.9) menganalisis isi dan kebahasan novel, juga KD (4.9) merancang novel atau novelet dengan memerhatikan isi dan kebahasaan baik secara lisan maupun tulis (Fitriyani, Bagiya, \& Santoso, 2018).

KD di atas berhubungan erat dengan Aplikasi IOOI Majas, di mana aplikasi ini dijadikan sebagai media pembelajaran yang mampu memudahkan pembelajaran majas bagi siswa. Hal itu sesuai dengan pendapat Nurseto (201I) bahwa media pembelajaran dapat membantu mempercepat proses belajar, sebagai sarana yang dapat mewujudkan situasi pembelajaran menjadi lebih efektif (Shalikhah, 2017), dan mampu meningkatkan kualitas proses belajar mengajar (Tafonao, 2018). Proses belajar mengajar dituntut 
untuk mengikuti kompetensi abad 2I untuk menghadapi tantangan yang lebih kompleks disertai dengan berbagai pengetahuan keterampilan dan media maupun teknologi (Muhali, 2019).

\section{SIMPULAN}

Pada penelitian ini, penerapan Aplikasi IO0I Majas guna mempermudah pemahaman mengenai majas pada siswa SMA di Kota Malang yang menjadi fokus utama. Hasil penelitian menunjukkan bahwa penerapan Aplikasi IOOI Majas mampu memudahkan pemahaman mengenai majas dalam pembelajaran bahasa Indonesia. Selain itu, keberadaan Aplikasi IOOI Majas juga dapat berperan sebagai media pembelajaran yang dapat memberikan manfaat yang berguna pada siswa. Siswa lebih mudah memahami majas melalui konten yang ada di Aplikasi IOOI Majas seperti materi, komik, dan permainan. Kontenkonten tersebut tidak terdapat dalam aplikasi majas lainnya. Siswa yang ingin membuat karya sastra pun dapat terbantu dengan adanya aplikasi ini. Selain itu, siswa dengan mudah dapat memilih majas untuk meningkatkan nilai estetika dalam menyusun karya sastra. Dengan adanya aplikasi ini, siswa dapat mempelajari majas kapan saja dan dimana saja karena mudah diakses. Oleh karena itu, disarankan agar guru dan siswa menggunakan Aplikasi IOOI Majas ini dalam proses pembelajaran bahasa Indonesia guna memudahkan pemahaman terhadap majas.

\section{UCAPAN TERIMA KASIH}

Penulis mengucapkan terima kasih kepada Program Studi Pendidikan Bahasa Indonesia FKIPUMM, yang telah memberikan kesempatan kepada penulis untuk melakukan penelitian ini melalui Pekan Ilmiah Nasional Mahasiswa. Selain itu, penulis juga mengucapkan terima kasih kepada dua SMA di Malang atas kerja sama, keterbukaan, ketersediaan data serta seluruh pengelola jurnal KEMBARA.

\section{DAFTAR PUSTAKA}

Anggraini, W. R., Sumantri, D. A., Purnomo, S. I., \& Anggraini, P. (2019). Pengembangan media pembelajaran majas berbasis teknologi. Deiksis: Jurnal Pendidikan Bahasa dan Sastra Indonesia, 6(I), I-8. doi: http:/ / dx.doi.org/I0.33603/deiksis.v6iI.I322

Dermawan, R. N., \& Santoso, J. (2017). Pemakaian majas dalam novel Anak Semua Bangsa karya Pramoedya Ananta Toer: Studi stiliska. CARAKA, 3(2), 16-35. doi: http:/ / dx.doi.org/I0.30738/caraka.v3i2.1828

Dhieni, N., \& Fridani, L. (2007). Metode pengembangan bahasa: Hakikat perkembangan bahasa anak. Semarang: IKIP Veteran.

Ekoyanantiasih, R. E. (2015). Majas metafora dalam pemberitaan olahraga di media massa cetak. $\begin{array}{llll}\text { Pujangga, } & I(\mathrm{I}), & \text { I5-23. } & \text { Retrieved }\end{array}$ http://journal.unas.ac.id/pujangga/article/view/I46/68

Fitriyani, F., Bagiya, B., \& Santoso, S. D. (2018). Penggunaan majas dalam Novel Cinta di Ujung Sajadah karya Asma Nadia dan skenario pembelajarannya di kelas XII SMA. SURYA BAHTERA, 6(52), 344-352. Retrieved from http://ejournal.umpwr.ac.id/index.php/suryabahtera/article/view/5452

Hakiky, L. B. D. (2020). Implementasi penggunaan media pembelajaran digital game based learning terhadap motivasi belajar dan keterampilan gerak dasar shooting bola basket. Jurnal Penelitian Pendidikan, 20(I), 72-82. Retrieved from https:/ / ejournal.upi.edu/index.php/JER/article/view/24555/I I839

Husain, C. (20I4). Pemanfaatan teknologi informasi dan komunikasi dalam pembelajaran di SMA Muhammadiyah Tarakan. Jurnal Kebijakan dan Pengembangan Pendidikan, 2(2). doi: I0.222I9/jkpp.v2i2.19I7

Indonesia, T. P. P. B. (2016). Pendoman Umum Ejaan Bahasa Indonesia yang Disempurnakan. Jakarta: Badan Pengembangan dan Pembinaan Bahasa Kementerian Pendidikan dan Kebudayaan.

Indriyani, D., Sukirno, S., \& Bagiya, B. (20I4). Analisis majas novel Cinta di dalam Gelas karya Andrea Hirata dan skenario pembelajarannya di kelas X SMA. SURYA BAHTERA, 2(I5), I-5. 
Retrieved

from

bahtera/article/view/4978/4562

http:/ / ejournal.umpwr.ac.id/index.php/surya-

JPNN. (2016). Pengguna Bahasa Indonesia 360 Juta Orang.

Kartikasari, G. (20I6). Pengaruh media pembelajaran berbasis multimedia terhadap motivasi dan hasil belajar materi sistem pencernaan manusia: studi eksperimen pada Siswa Kelas V MI Miftahul Huda Pandantoyo. Jurnal Dinamika Penelitian: Media Komunikasi Penelitian Sosial Keagamaan, I6(I), 59-77. doi: I0.2I274/dinamika.2016.16.I.59-77

Kastolani, W. (2015). Pengembangan model pembelajaran sts (science-technology society) untuk meningkatkan kepedulian mahasiswa terhadap lingkungan hidup pada matakuliah ekologi manusia. Jurnal Penelitian Pendidikan, I5(I), I-9. Retrieved from https://ejournal.upi.edu/index.php/JER/article/view/I279/893

Lubis, I. R., \& Ikhsan, J. (2015). Pengembangan media pembelajaran kimia berbasis android untuk meningkatkan motivasi belajar dan prestasi kognitif peserta didik SMA. Jurnal Inovasi Pendidikan IPA, I(2), I9I-20I. doi: https:/ / doi.org/I0.2I83I/jipi.vIi2.7504

Maharani, Y. (2015). Efektivitas multimedia pembelajaran interaktif berbasis kurikulum 2013. Indonesian Journal of Curriculum and Educational Technology Studies, 3( I), 3I -40. Retrieved from https:/ / www.learntechlib.org/author/Yuli+Maharani/

Muhali, M. (2019). Pembelajaran inovatif abad ke-2I. Jurnal Penelitian dan Pengkajian Ilmu Pendidikan: e-Saintika, 3(2), 25-50. doi: https://doi.org/I0.363I2/e-saintika.v3i2.126

Muhson, A. (2010). Pengembangan media pembelajaran berbasis teknologi informasi. Jurnal Pendidikan Akuntansi Indonesia, 8(2). doi: https://doi.org/I0.2183I/jpai.v8i2.949

Munawar, \& Sufa'atin. (2016). Pembangunan aplikasi media pembelajaran dan simulasi troubleshooting televisi. KOMPUTA-Jumal Komputer \& Informatika, 4(I), I-IO. doi: I0.340I0/KOMPUTA.V4II.240I

Munir, S. (2013). Diksi dan majas dalam kumpulan puisi Nyanyian dalam Kelam Karya Sutikno WS: Kajian stilistika. Jurnal Sastra Indonesia, 2( I), I-IO.

Nurseto, T. (20I I). Membuat media pembelajaran yang menarik. Jurnal Ekonomi dan pendidikan, 8(I), I9-35. doi: https://doi.org/I0.2183I/jep.v8iI.706

Oktaviani, I., \& Marginingsih, M. (2018). Prototype Media Pembelajaran Berbasis Multimedia Jurnal Informa, 4(3), I4-I9. doi: https:// doi.org/10.46808/informa.v4i3.55

Permana, I. (2017). Majas kiasan dalam naskah berita sepak bola di harian berita olahraga Topskor. Semantik, 3(I). doi: https://doi.org/I0.22460/semantik.v3iI.p\%25p

Pradopo, R. D. (2017). Beberapa Teori Sastra, Metode Kritik, dan Penerapannya. Jakarta: Pustaka Pelajar.

Pujiastuti, D., Idrus, A., \& Emosda, E. (20I4). Pengembangan media pembelajaran PKn berbasis multimedia interaktif untuk SMP kelas VIII. Jurnal Tekno-pedagogi, 4(I), 30-4I. Retrieved from https:// online-journal.unja.ac.id/pedagogi/article/view/2245

Santoso, S. (2016). Majas dalam Novel Semesta Mendukung Karya Ayuwidya. Jurnal Bastra, 2(I). Retrieved from http://ojs.uho.ac.id/index.php/BASTRA/article/view/I528/I08I

Shalikhah, N. D. (2017). Media pembelajaran interaktif lectora inspire sebagai inovasi pembelajaran. Warta LPM, 20(I), 9-I6. doi: I0.239I7/warta.vI9i3.2842

Sugiarti, D. (20I5). Pembuatan buku cerita bergambar dengan tokoh Gatotkaca sebagai media pembelajaran kelas B TK Khalifah Surabaya. Jurnal Seni Rupa, 3(I), 64-69. Retrieved from https://jurnalmahasiswa.unesa.ac.id/index.php/va/article/view/I0380/I0I28

Susanti, N., Abdurahman, A., \& Ismail, M. (2013). Majas dalam novel Bidadari-Bidadari Surga karya Tere Liye. Pendidikan Bahasa Indonesia, I(2), 356-362. doi: https:/ / doi.org/I0.24036/I338019883

Tafonao, T. (2018). Peranan media pembelajaran dalam meningkatkan minat belajar mahasiswa. Jurnal Komunikasi Pendidikan, 2(2), I03-I I4. doi: https://doi.org/I0.32585/jkp.v2i2.II3 
Wahyuni, H. F., Semi, M. A., \& Hamidin, H. (2012). Majas dalam lirik lagu album top hits Elly Kasim volume 2. Pendidikan Bahasa Indonesia, I(I), 364-37I. doi: https://doi.org/I0.24036/423019883

Wulandari, R. A., Suyanto, E., \& Fuad, M. (2015). Majas dalam kumpulan puisi dan pembelajarannya di SMA. Jurnal Kata (Bahasa, Sastra, dan Pembelajarannya), 3(3), I-I0. Retrieved from http://jurnal.fkip.unila.ac.id/index.php/BINDOI/article/view/I040I/7I I2

Yektyastuti, R., \& Ikhsan, J. (2016). Pengembangan media pembelajaran berbasis android pada materi kelarutan untuk meningkatkan performa akademik siswa SMA. Jurnal Inovasi Pendidikan IPA, 2(I), 88-99. doi: https:// doi.org/I0.2I83I/jipi.v2iI.I0289

Yono, R. R., \& Mulyani, M. (2017). Majas dan citraan dalam Novel Kerling Si Janda Karya Taufiqurrahman Al-Azizy. Seloka: Jurnal Pendidikan Bahasa Dan Sastra Indonesia, 6(2), 200207. Retrieved from https://journal.unnes.ac.id/sju/index.php/seloka/article/view/I7286 